\title{
The Beirut Branch
}

Robert Klonoski, Mary Baldwin College, USA

\begin{abstract}
In response to the takeover of the American Embassy in Iran in 1979, President Jimmy Carter issued two executive orders freezing assets owned by the Iranian government and by Iranian citizens and held by U.S. financial institutions. The case examines an incident that arose following the implementation of these orders and examines (1) the use of global businesses as instruments of foreign policy; (2) issues of cross-cultural communication and trust; and (3) crisis management. The case may be useful for classes in international business, in negotiation, and in conflict resolution.
\end{abstract}

Keywords: Trust; negotiation; international; cross-cultural; role of government; overseas offices; confrontation

\section{BACKGROUND}

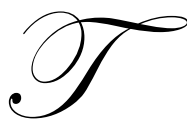

he International Bank and Trust was founded in the 1800's and was one of the first banks chartered in the United States to open overseas offices. The bank is headquartered in New York City and ranks among the world top 100 financial institutions in terms of asset size and profitability. While a majority of its stock is owned by US nationals, significant minority interests are held by British and Saudi investors. In the mid-1950's, the International Bank and Trust opened a branch in Beirut, Lebanon. At the time of the events described below, approximately two thirds of the bank's profits came from its international operations.

\section{THE BRANCH}

Based in New York, Ted Baker was promoted to the position of regional manager for the Mid-East after a successful two year term running the area office for Australia and New Zealand in 1970/71. His practice of hiring local managers to run the overseas branches was a novel managerial approach; past practice had been to hire local people for the staff positions, but to appoint an ex-pat in the managerial role. Ted's approach had worked out very well. The new managers had used their understanding of the local practices and their relationships with businesses and investors to the bank's advantage.

By the 1970's, the Beirut branch had become a thriving office. Ted hired Rashid in 1973 to manage the Beirut office. Born in Lebanon and educated in Cairo, Rashid had spent his early career in financial services in several locations throughout the Mid-East, but this was his first experience working for a US-based company. Under Rashid's guidance, the branch was able to build a sizable client base of wealthy investors from countries throughout the region - from Turkey to Pakistan. Private banking services were provided to wealthy individuals, including a full array of investment, currency translation and transfer services.

By placing funds in a bank based in a country in which there is a possibility of political unrest or a hostile takeover, a depositor runs the risk that his or her funds may be confiscated by a new regime. The money center banks of London, Tokyo and New York were felt to be free of such risk and came to be known as "safe havens".

\section{THE INCIDENT}

On November 4, 1979, a group of students led by Ebrahim Asgharzadeh overran the US Embassy in Iran, taking 53 American hostages. President Jimmy Carter attempted to negotiate with the government of Iran, but when initial efforts were unsuccessful, he decided to take action. Executive Order 12170 required American companies holding the assets of the Iranian government or its agencies to "freeze" those assets, that is, not to confiscate the funds but to deny the owners access to them. 
This executive order, along with the other actions taken by the United States did not resolve the hostage situation. On April 7, 1980, the freeze on Iranian assets was expanded by Executive Order 12205 to include funds owned by people residing in Iran as well as those of any organization controlled by an Iranian citizen.

Rashid received his orders on the morning of April 8. He was to identify any assets held by Iranian nationals or Iranian owned businesses and to transmit the funds to New York for safe keeping. Rashid considered his position. The local sentiment favored the Iranians. His investors were wealthy and, very often, powerful. Rashid knew he had very little time to decide whether or not he would comply with the directions of his manager.

Rashid cabled Ted with the following: "Confiscating funds of Iranian nationals difficult to implement. Lebanese courts will not likely support order issued by US President. Defeats our position as a safe haven. Significant money involved so local staff at safety risk. Sorry, cannot comply. Please advise."

\section{THE NEW YORK REACTION}

The cable had arrived at the bank's head office at 9:00am New York time, meaning that it was 4:00pm in Beirut. The office would be closing in one hour; while it would be possible to contact Rashid at his home, if any had to be taken that would involve direct contact between Ted and the other employees of the branch, the only reliable communication would have to happen by placing a call to the branch while it was still open.

The consequences of disobeying the executive order were not clearly laid out in the order itself, but Ted and his fellow managers knew that civil and or criminal penalties might apply. Moreover, there would be public scrutiny of the bank's actions. Ted knew that he had to act quickly.

\section{ANALYSIS QUESTIONS}

- What responsibility does Ted have to the employees in the Beirut branch? What responsibility does Ted have to comply with Executive Order 12205?

- What are Rashid's responsibilities to his customers? To his employees?

- $\quad$ Discuss the concept of an international company versus a US company with overseas offices.

- Discuss the issues of the case in terms of trust and communication. How should Ted approach his negotiations with Rashid?

\section{REFERENCES}

1. Executive Order 12170, downloaded November 3, 2009 from: http://www.archives.gov/federalregister/codification/executive-order/12170.html

2. Executive Order 12205, downloaded November 3, 2009 from: http://www.archives.gov/federalregister/codification/executive-order/12205.html 


\section{FOOTNOTES}

\section{$\underline{\text { Executive Order 12170 - Issued 14-Nov-1979 }}$}

Pursuant to the authority vested in me as President by the Constitution and laws of the United States including the International Emergency Economic Powers Act, 50 U.S.C.A. sec. 1701 et seq., the National Emergencies Act, 50 U.S.C. sec. 1601 et seq., and 3 U.S.C. sec. 301.

I, JIMMY CARTER, President of the United States, find that the situation in Iran constitutes an unusual and extraordinary threat to the national security, foreign policy and economy of the United States and hereby declare a national emergency to deal with that threat.

I hereby order blocked all property and interests in property of the Government of Iran, its instrumentalities and controlled entities and the Central Bank of Iran which are or become subject to the jurisdiction of the United States or which are in or come within the possession or control of persons subject to the jurisdiction of the United States.

The Secretary of the Treasury is authorized to employ all powers granted to me by the International Emergency Economic Powers Act to carry out the provisions of this order.

This order is effective immediately and shall be transmitted to the Congress and published in the Federal Register.

\section{Executive Order 12205 - Issued 7-Apr-1980}

By the authority vested in me as President by the Constitution and statutes of the United States, including Section 203 of the International Emergency Economic Powers Act (50 U.S.C. 1702), Section 301 of Title 3 of the United States Code, and Section 301 of the National Emergencies Act (50 U.S.C. 1631), in order to take steps additional to those set forth in Executive Order No. 12170 of November 14, 1979, to deal with the threat to the national security, foreign policy and economy of the United States referred to in that Order, and in furtherance of the objectives of United Nations Security Council Resolution 461 (1979) adopted on December 31, 1979, it is hereby ordered as follows:

1-101. The following are prohibited effective immediately, notwithstanding any contracts entered into or licenses granted before the date of this Order:

(a) The sale, supply or other transfer, by any person subject to the jurisdiction of the United States, of any items, commodities or products, except food, medicine and supplies intended strictly for medical purposes, and donations of clothing intended to be used to relieve human suffering, from the United States, or from any foreign country, whether or not originating in the United States, either to or destined for Iran, an Iranian governmental entity in Iran, any other person or body in Iran or any other person or body for the purposes of any enterprise carried on in Iran.

(b) The shipment by vessel, aircraft, railway or other land transport of United States registration or owned by or under charter to any person subject to the jurisdiction of the United States or the carriage (whether or not in bond) by land transport facilities across the United States of any of the items, commodities and products covered by paragraph (a) of this section which are consigned to or destined for Iran, an Iranian governmental entity or any person or body in Iran, or to any enterprise carried on in Iran.

(c) The shipment from the United States of any of the items, products and commodities covered by paragraph (a) of this section on vessels or aircraft registered in Iran.

(d) The following acts, when committed by any person subject to the jurisdiction of the United States in connection with any transaction involving Iran, an Iranian governmental entity, an enterprise controlled by Iran or an Iranian governmental entity, or any person in Iran:

i. $\quad$ Making available any new credits or loans;

ii. Making available any new deposit facilities or allowing substantial increases in non-dollar deposits which exist as of the date of this Order; 
iii. Allowing more favorable terms of payment than are customarily used in international commercial transactions;

iv. Failing to act in a businesslike manner in exercising any rights when payments due on existing credits or loans are not made in a timely manner; or

v. Make any payment, transfer of credit, or other transfer of funds or other property or interests therein, except for purposes of family remittances.

(e) The engaging by any person subject to the jurisdiction of the United States in any service contract in support of an industrial project in Iran, except any such contract entered into prior to the date of this Order or concerned with medical care.

(f) The engaging by any person subject to the jurisdiction of the United States in any transaction which evades or avoids, or has the purpose or effect of evading or avoiding, any of the prohibitions set forth in this section.

[Para. 1-101 amended by Executive Order 12211 of Apr. 17, 1980, 45 FR 26685, 3 CFR, 1980 Comp., p. 253]

1-102. The prohibitions in section 1-101 above shall not apply to transactions by any person subject to the jurisdiction of the United States which is a non-banking association, corporation, or other organization organized and doing business under the laws of any foreign country.

1-103. The Secretary of the Treasury is delegated, and authorized to exercise, all functions vested in the President by the International Emergency Economic Powers Act (50 U.S.C. 1701 et seq.) to carry out the purposes of this Order. The Secretary may redelegate any of these functions to other officers and agencies of the Federal government.

1-104. The Secretary of the Treasury shall ensure that actions taken pursuant to this Order and Executive Order No. 12170 are accounted for as required by Section 401 of the National Emergencies Act (50 U.S.C. 1641).

1-105. This Order is effective immediately. In accord with Section 401 of the National Emergencies Act (50 U.S.C. 1641) and Section 204 of the International Emergency Economic Powers Act (50 U.S.C. 1703), it shall be immediately transmitted to the Congress and published in the Federal Register. 


\section{CASE DISCUSSION}

In this case, extrinsic factors have created a tense situation within the Middle Eastern operations of the International Bank and Trust. President Jimmy Carter created a role for international companies that was beyond the scope of their original charters - to assist in the execution of foreign policy. A task of this nature might be adopted and accomplished more easily when the government provides its own safety and security functions, but here the mandate of the US government extended to foreign lands where neither of these protections was present.

\section{The Responsibilities of Ted and Rashid}

The case concerns how each level of management defined its priorities and, therefore, its negotiating position. Rashid is concerned about the welfare of the people within his employ, the local branch personnel who might be at risk if the assets of several of his wealthy and powerful clients are, in his words, "confiscated." He is also concerned about his clients and the funds he has convinced them to deposit with the International Bank and Trust. Finally, he feels that the business model, that of providing banking services free of political influence, is being compromised.

Ted, on the other hand, is being compelled to comply with an Executive Order - something which has the effect of law, and for which non-compliance could carry criminal penalties. Although distantly related to the case, Ted may also be concerned about the hostages in Iran, and want to participate in the solution proposed by President Carter in the hope that he may assist in resolving that crisis.

The International Bank and Trust had been acting in the manner of an international organization. It had offered products and services which were of use to customers in the local market of the Mid-East, and had hired people from the area who understood and abided by local customs and practices in applying its products to the market. The local management shared a basic organizational goal of growing the business and was hired, in part, because of a willingness to use personal contacts to assist in accomplishing this. Regional management had conceived of this structure and was using it to the benefit of the organization.

What then happens when an exogenous shock causes regional management to abandon the psychological contract it had created with local management? If trust had developed between Ted and Rashid, how deeply might this reversal threaten that relationship? The conflict between Ted and Rashid has been triggered by an upheaval of priorities on the part of management, and the very short time frame within which a solution must be found adds intensity to the situation.

Rashid, enmeshed in his own local branch business, involved with friends and business contacts whose trust he is being directed to violate and concerned for the safety of his staff, objected to the order. The answer he gave focused only on the world in which he lived; it is uncertain whether he assessed the international setting in which the whole organization exists or considered the set of options immediately available to Ted. Whether the immediate environment of his branch created bounds for his decision making or was merely his priority, the effect was the same.

Instead of treating the situation as an arms-length problem to be solved, (see: Follett, 2005, p. 154) both the regional and local manager treated the situation as a question of loyalty, and their priorities caused them to take different positions.

\section{An International Organization}

Organizations that operate in the global environment are subject to political risk. In this instance, the United States sought to make the bank, along with other organizations involved in international commerce, agents of its foreign policy. The involvement of business in the implementation of government policy is neither new nor unique to the United States. The current ban by the U.S. and the European Union on importing from, exporting to or exchanging currency with Myanmar is an example of this. 
If the headquarters of the International Bank and Trust had been in the Cayman Islands, if a majority of the stockholders had been non-US based, or if the Beirut office had been structured as a joint venture with a Lebanese bank, the US would still have been able to leverage access to US markets as its bargaining position in negotiating for compliance, but it would have had a weaker legal basis for compelling the bank to execute the order. It would only be able to revoke a license for operating on US territory rather than to close the entire business and it would have had less authority to threaten executives with criminal action for noncompliance.

In this case, the International Bank and Trust was compelled to act as a US corporation with overseas offices. Whether or not it would have complied with the executive order had it the ability to choose is not a consideration; the fact of it being headquartered in New York gave the US government a sufficient legal basis for controlling its actions.

\section{The Negotiation}

As the regional manager, Ted would have had the opportunity to set the stage for critical debate and open communication (Ayoko, 2006, p. 350). Rashid's opening statement of non-compliance may have been an emotional reaction, an opening ploy for a negotiation, or evidence of a poor communication channel with his manager. It does, however, demonstrate that Ted's authority over the situation has been compromised, as Rashid's position indicates that he values his customers and employees more than whatever reward or deprivation Ted is capable of delivering (See: Bachrach \& Baratz, 1963, p. 635).

Depending on the strength of their relationship before the start of this crisis, both Rashid and Ted may be simultaneously experiencing feelings of trust and distrust for each other. (See: Lewicki, 1998, p. 448). While each may have understood the legitimacy of the other's goals and interests, both weighed their positions and arrived at different assessments of the relevant priorities. Both may be experiencing uncertainty about their courses of action, limited by the options they see in front of them and forced to take action they understand to be leading to conflict. The scenario is well characterized by Simon's (2006, p. 96) statement that "The toughest challenges in decision making may be those where the options are clear but present powerfully conflicted desires."

The directive to identify and freeze the Iranian assets showed little sensitivity to the local situation. Rashid's stated position, that he will not comply with the order, reflects his underlying interests - ensuring the safety of his staff, the "safe haven" reputation of his business, and the financial assets of some of his principal clients. Ted may be able to negotiate effectively with Rashid if he understands the distinction between Rashid's stated position and the interests Rashid is seeking to appease (Bazerman, 2009, p. 153).

Rashid, by announcing a contrarian position, has set a stage where non-rational escalation of the conflict is a very real possibility (Bazerman, 2009, p. 172, citing Staw). It is Ted's turn to respond. He must do so in a way which creates a positive value for Rashid (Bazerman, 2009, p. 169) and enable him to offer each of his principal stakeholders some accommodation.

\section{GENERAL COMMENTS}

Given the relatively short time frame in which the decision must be made, the case presents an opportunity for in-class discussion as an exercise in negotiation and trust-building and can be accomplished in a single session.

\section{AUTHOR INFORMATION}

Robert Klonoski is an Assistant Professor of Business Administration at Mary Baldwin College in Virginia, USA. His research interests include educational technologies and work motivation.

He has also taught at the University of the District of Columbia, the University of Virginia and has worked in the financial services industry. Professor Klonoski holds a B.S. in Finance from Fairfield University, an M.B.A. from the University of Connecticut, and a J.D. from Brooklyn Law School. He is currently completing his Doctorate in Management at the University of Maryland, University College. 


\section{REFERENCES}

1. Ayoko, O. \& Hartel, C. (2006). Cultural diversity and leadership: A conceptual model of leader intervention in conflict events in culturally heterogeneous workgroup. Cultural Management, 13(4), 345360. DOI: 1219803841.

2. Bachrach, P. \& Baratz, M. (1963). Decisions and Non-Decisions: An Analytical Framework. American Political Science Review, 57(3), 632-42.

3. Bazerman, M. \& Moore, D. (2009). Judgment in Managerial Decision Making, $7^{\text {th }} e d$. Hoboken, NJ: John Wiley \& Sons.

4. Follett, M. (2005). The Giving of Orders. In J. Shafritz, J.S. Ott and Y. Jang (Eds.) Classics of Organization Theory $6^{\text {th }}$ ed. Belmont, CA: Thomson Wadsworth, 152-157.

5. Lewicki, R., McAllister, D., \& Bies, R. (1998). Trust and Distrust: New Relationships and Realities. Academy of Management Review, 23(3), 438-458.

6. Simon, A. (2006) Leadership and Managing Ambivalence. Consulting Psychology Journal. 58(2), 91-105. 


\section{NOTES}

